\title{
SISTEM PAKAR MENENTUKAN KEKURANGAN UNSUR HARA DAN PENGGUNAAN PUPUK PADA TANAMAN JAGUNG PASCA PENANAMAN MENGGUNAKAN METODE FORWARD CHAINING (FC)
}

\author{
Ahmad Fauzi ${ }^{1}$, Desi Andreswari ${ }^{2}$, Bambang Gonggo Murcitro ${ }^{3}$ \\ ${ }^{1,2}$ Program Studi Informatika, Fakultas Teknik, Universitas Bengkulu \\ ${ }^{3}$ Program Studi Ilmu Tanah, Fakultas Pertanian, Universitas Bengkulu

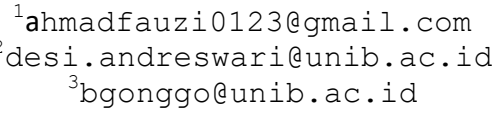

Abstrak: Jagung merupakan salah satu tanaman pangan yang banyak dibudidayakan di dunia. Indonesia salah satu negara yang memiliki potensi yang sangat besar dalam sektor Pertanian, maka diperlukan berbagai upaya untuk meningkatkan hasil panen salah satunya dengan melakukan pemupukan yang baik dan benar. tanaman jagung sangat rentan dengan kekurangan unsur hara, Penelitian ini bertujuan untuk menghasilkan Sistem pakar menentukan kekurangan unsur hara dan penggunaan pupuk pada tanam jagung pasca penanaman menggunakan metode forward chaining (FC). Gejala yang terdapat pada sistem sebanyak 32 gejala dari seluruh gejala yang ada baik pada daun, batang, akar dan tongkol jagung. Sistem pakar ini dibuat menggunakan MySQL sebagai database, PHP (Hypertext Preprocessor) untuk bahasa pemrograman dan UML (Unified Modeling Languange) sebagai pemodelan perancangan perangkat lunak (software). Pengujian sistem dilakukan dengan dua tahap yaitu Black Box Testing dan White Box Testing, sedangkan untuk pengujian kelayakan sistem menggunakan Skala Liker dan Probabiltas Klasik. Jumlah responden yang diajukan sebanyak 31 orang, kuesioner terdiri atas 8 pertanyaan. 4 tentang tampilan sistem dan 4 tentang kemudahan menggunakan sistem. perolehan yang didapat untuk tampilan sistem dengan rata-rata persentase $90,49 \%$ termasuk ke dalam interval "Sangat Baik", kemudahan menggunakan aplikasi dengan rata-rata persentase sebesar 82,67 \% termasuk ke dalam interval "Baik" dan hasil dari uji kelayakan diperoleh presentase sebesar 53,12\% jadi sistem dapat dikatakan Layak.

Kata Kunci: Forward Chaining, MySQL, PHP, Unsur Hara, Tanaman Pangan.

Abstract: Corn is one of the many cultivated food crops in the world. Indonesia is one country that has enormous potential in the Agriculture sector, so it takes various efforts to increase yields, one of them is by applying good and right fertilization. Corn plants are very susceptible to nutrient deficiencies. This study aims to produce an expert system to determine nutrient deficiencies and fertilizer use in post-planting corn planting using the forward chaining (FC) method. Symptoms found in the system as many as 32 symptoms of all symptoms that exist both in leaves, stems, roots and corn cobs. This expert system is created using MySQL as a database, PHP (Hypertext Preprocessor) for programming languages and UML (Unified Modeling Language) as software design modeling. System testing is carried out in two stages, namely Black Box Testing and White Box Testing, while for testing the feasibility of the system using the Classic Liker and Probability Scale. The number of respondents submitted was 31 people, the questionnaire consisted of 8 questions. 4 about the appearance of the system and 4 about the ease of using the system. the acquisition obtained for the display system with an average percentage 
Jurnal Pseudocode, Volume V Nomor 2, September 2018, ISSN 2355-5920, e-ISSN 2655-1845 www.ejournal.unib.ac.id/index.php/pseudocode

of $90.49 \%$ included in the interval "Very Good", the ease of using the application with an average percentage of $82.67 \%$ included in the interval "Good" and the results of the feasibility test obtained a percentage of $53.12 \%$ so the system can be said to be Decent.

Keywords: Forward Chaining, MySQL, PHP, Nutrient Elements, Plant Food

\section{PENDAHULUAN}

Indonesia memiliki kekayaan alam yang sangat melimpah sehingga membuat negara Indonesia menjadi salah satu negara yang memiliki potensi sangat besar dalam sektor pertanian. Salah satu hasil pertanian yaitu Jagung merupakan salah satu tanaman pangan dunia yang terpenting, selain gandum dan padi. Sebagai sumber karbohidrat utama jagung juga menjadi alternatif sumber pangan Penduduk beberapa daerah di Indonesi. Untuk mewujudkan hal itu diperlukan berbagai upaya, diantaranya meningkatkan produktivitas jagung melalui penerapan teknologi dengan pemupukan yang baik dan benar agar hasil panen dapat melimpah. Pemupukan merupakan salah satu usaha pengelolaan kesuburan tanah. Berdasarkan hasil dari penelitian yang telah dilakukan, maka pada penelitian ini digunakan motode Forward Chaining dimana metode ini akan dapat menangani masalah kekurangan unsur hara pada tanaman jagung dan memberikan solusi dari permasalaah yang ada [1].

Cara kerja dari metode ini dengan pencarian yang dimulai dengan fakta yang diketahui, kemudian mencocokkan fakta-fakta tersebut dengan bagian IF dari rules IF-THEN. Bila ada fakta yang cocok dengan bagian IF, maka rule tersebut dieksekusi. Bila sebuah rule dieksekusi, maka sebuah fakta baru (bagian THEN) ditambahkan ke dalam database. Setiap kali pencocokan, dimulai dari rule teratas. Setiap rule hanya boleh dieksekusi sekali saja. Proses pencocokan berhenti bila tidak ada lagi rule yang bisa dieksekusi.

\section{LANDASAN TEOR}

\section{A. Jagung}

Jagung (Zea mays) merupakan salah satu yang bernilai ekonomis serta mempunyai peluang untuk dikembangkan karena ke-dudukannya sebagai sumber utama karbohidrat dan protein setelah beras. Hampir seluruh bagian tanaman jagung dapat dimanfaatkan untuk berbagai macam keperluan. Batang dan daun tanaman yang masih muda dapat digunakan untuk pakan ternak, yang tua (setelah dipanen) dapat digunakan untuk pupuk hijau atau kompos. Saat ini cukup banyak yang memanfaatkan batang jagung untuk kertas. Kegunaan lain dari jagung adalah sebagai pakan ternak, bahan baku farmasi, dextrin, perekat, tekstil, minyak goreng, dan etanol. Permintaan jagung meningkat dari tahun ke tahun sejalan dengan meningkatnya jumlah penduduk dan industri [2].

\section{B. Tanah}

Tanah adalah bagian permukaan bumi yang terdiri dari mineral dan bahan organik. Tanah sangat penting peranannya bagi semua kehidupan di bumi, karena tanah mampu mendukung kehidupan tumbuhan di mana tumbuhan menyediakan makanan dan oksigen kemudian menyerap karbon dioksida dan nitrogen. Dalam mendukung kehidupan tanaman, tanah memiliki fungsi untuk memberikan unsur hara dan sebagai media perakaran, menyediakan air dan sebagai tempat penampungan (reservoar) air, menyediakan udara untuk respirasi akar dan sebagai tempat bertumpunya tanaman [3].

C. pH Tanah 
Jurnal Pseudocode, Volume VI Nomor 2, September 2019, ISSN 2355-5920, e-ISSN 2655-1845 www.ejournal.unib.ac.id/index.php/pseudocode

Kondisi kemasaman (ph) dalam tanah berkisar antara netral sampai agak masam. hal ini bisa terjadi karena kandungan bahan organik tanah yang rendah dan pencucian basa-basa oleh air pada saat erosi sehingga menyebabkan ph tanah menjasi masam. peningkatkan ph yang terjadi karena pengapuran mempengaruhi berbagai proses sepert: memperkecil pengaruh langsung yang merugikan dari ph yang terlalu masam, meningkatnya ketersediaan unsur hara, dan menekan efek meracun dari kelebihan AL,Fe dan Mn pada tanah masa. tingkat keasaman atau kebasahan suatu benda yang diukur dengan menggunakan skala $\mathrm{pH}$ antara 0 hingga 14. Sifat asam mempunyai $\mathrm{pH}$ antara 0 hingga 7 dan sifat basa mempunyai nilai pH 7 hingga 14 pada jagung ph yang dibutuhkan sekitar 5.5-7 [4].

\section{Unsur Hara}

Sebagai makhluk hidup yang tumbuh dan berkembang, setiap tanaman tentu membutuhkan makanan. Makanan tersebut bisa didapat dari unsur hara. Yaitu suatu zat yang dapat memberi pengaruh terhadap pertumbuhan dan juga perkembangan fisik pada tanaman. Semua tanaman harus mampu memenuhi kebutuhan seluruh unsur hara dalam jumlah yang tepat demi menyempurnakan pertumbuhan dan beberapa manfaat tersebut demi perkembangan hidupnya. Sebab, unsur hara yang tidak terpenuhi secara menyeluruh dapat membuat pertumbuhan dan perkembangan tanaman menjadi terganggu sehingga proses pertumbuhan tak dapat berjalan normal dan maksimal.

Unsur hara yang diperlukan bagi tanaman terdiri dari 2 yaitu unsur hara makro dan mikro. Unsur hara makro adalah unsur hara yang diperlukan dalam jumlah banyak sedangkan
Unsur hara mikro adalah unsur hara yang diperlukan dalam jumlah yang sangat sedikit [5].

\section{E. Pupuk}

Pupuk didefinisikan sebagai suatu bahan yang diberikan ke dalam tanah untuk menaikkan produksi tanaman dalam keadaan lingkungan yang baik. Pemupukan dilakukan agar tanaman tumbuh dengan subur dan berproduksi optimal. Pemupukan didasarkan atas kebutuhan tanaman dan status hara tanah [6]. Manfaat pupuk yang paling banyak dirasakan adalah menyediakan unsur hara yang diperlukan bagi tanaman. Selain menyediakan unsur hara, pemupukan juga membantu mencegah kehilangan unsur hara yang cepat hilang, Pemberian pupuk juga membantu penyerapan unsur hara. Hal ini sangat penting, karena unsur hara berperan dalam pertumbuhan tanaman [7].

\section{Metodologi}

Jenis penelitian yang dilakukan adalah penelitian terapan (applied research) yang bertujuan untuk memberikan solusi atas permasalahan yang telah dipaparkan. Metode pengumpulan data yang dilakukan yaitu :

\section{Studi Pustaka}

Studi pustaka dilakukan dengan cara menelaah beberapa literatur, yaitu:

\section{a. Buku referensi}

Buku yang digunakan sebagai referensi adalah buku-buku yang membahas tentang sistem pakar, dasar-dasar ilmu tanah, budidaya jagung dan rekayasa perangkat lunak.

b. Jurnal ilmiah 
Jurnal Pseudocode, Volume V Nomor 2, September 2018, ISSN 2355-5920, e-ISSN 2655-1845 www.ejournal.unib.ac.id/index.php/pseudocode

Jurnal ilmiah yang digunakan diperoleh dengan cara mengunduhnya melalui internet. Informasi yang diperoleh adalah informasi yang membahas tentang sistem pakar pada tanaman jagung, dan sistem pakar yang menggunakan metode forward chaining.

2. Kuisioner

Kuisioner dilakukan dengan angket yang diisi oleh pengguna untuk mengumpulkan data. Selain itu data yang didapatkan berasal dari angket yang diisi oleh beberapa pedagang pupuk yang ada di kota Bengkulu.

Pengujian program dilakukan menggunakan dua metode, yaitu black box dan white box. Pengujian ini dilakukan untuk melihat apakah program sudah berjalan sesuai rancangan atau belum.

\section{ANAlisis Data Dan Perancangan}

\section{A. Analisis Sistem}

Sistem yang akan dibangun adalah aplikasi sistem pakar yang digunakan untuk mendiagnosa gejala kekurangan unsur hara dan penggunaan pupuk pada tanaman jagung berdasarkan gejala yang dialami. Aplikasi ini dibangun untuk dapat membantu petani dan masyarakat untuk dapat mengetahui lebih banyak lagi informasi tentang permasalahan yang sering terjadi pada tanaman jagung khususnya yang membahas masalah kekurangan unsur hara dan penggunaan pupuk. keluaran dari sistem ini adalah pengunaan pupuk sesuai gejala yang terjadi pada tanaman jagung, informasi penyebab kekurangan unsur hara dan penanganannya.
B. Analisis Kebutuhan Sistem
1. Kebutuhan Masukan (input)

Data yang dikumpulkan untuk memenuhi kebutuhan masukan antara lain data unsur hara, data pupuk, gejala-gejala kekurangan unsur hara, relasi antara gejala dan kekurangan unsur hara.

\section{Kebutuhan keluaran (output)}

Output yang dihasilkan adalah berupa aplikasi sistem pakar yang mampu mendeteksi kekurangan unsur hara berdasarkan gejala-gejala yang dialami oleh tanaman jagung dengan menggunakan aturan pada metode forward chaining serta mampu memberikan informasi unsur hara, pupuk, penyebab kekurangan unsur hara dan solusi dari permasalahan yang ada.

\section{Akusisi Pengetahuan}

Proses akusisi pengetahuan merupakan proses untuk menyusun basis pengetahuan.

\section{Pohon Keputusan}

Proses pencarian dari pohon keputusan dilakukan dari akar node awal dari yang paling kiri hingga yang paling akhir atau sampai dengan goal ditemukan kemudian metode yang digunakan adalah algoritme depth first search (DFS).

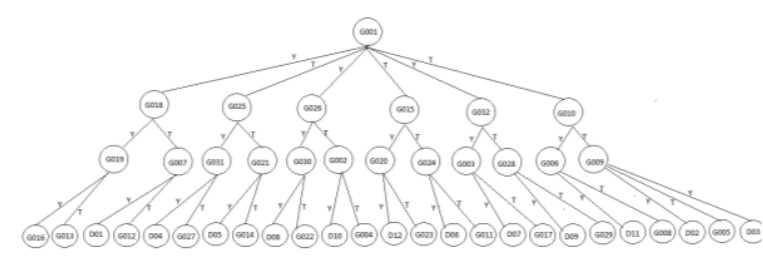

Gambar 1. Pohon Keputusan

\section{Perancangan Sistem}

Usecase mengambarkan fungsi dari sebuah sistem, Sebuah usecase merepresentasikan sebuah interaksi antara actor dan sebuah sistem yang akan dibuat. Dalam sistem ini terdiri dari 2 usecase yang terdiri dari usecase pengguna dan admin. 
Jurnal Pseudocode, Volume VI Nomor 2, September 2019, ISSN 2355-5920, e-ISSN 2655-1845 www.ejournal.unib.ac.id/index.php/pseudocode

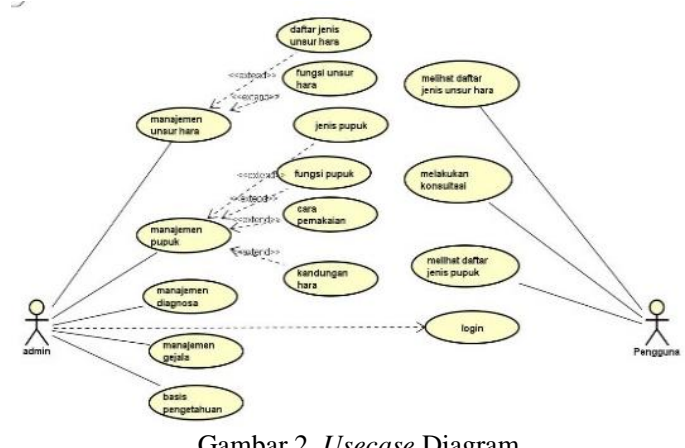

Gambar 2. Usecase Diagram

\section{HASIL DAN PEMBAHASAN}

Semua hypertext link dan bagian bookmark akan dihapus. Jika paper perlu merujuk ke alamat email atau URL di artikel, alamat atau URL lengkap harus diketik dengan font biasa.

\section{Halaman Pengguna}

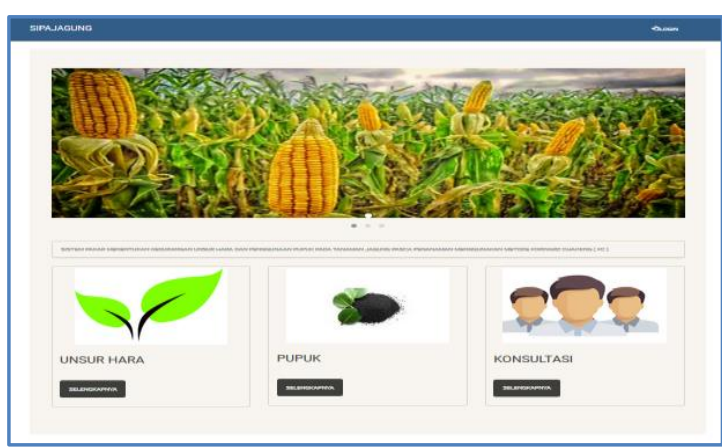

Gambar 3. Halaman Utama Website

Pada halaman utama website terdapat tiga menu yang bisa di akses oleh pengguna yaitu menu unsur hara, menu pupuk dan konsultasi dimana jika pengguna ingin mengakses atau memasuki salah satu menu tersebut, pengguna hanya cukup mengklik tulisan selengkapnya.

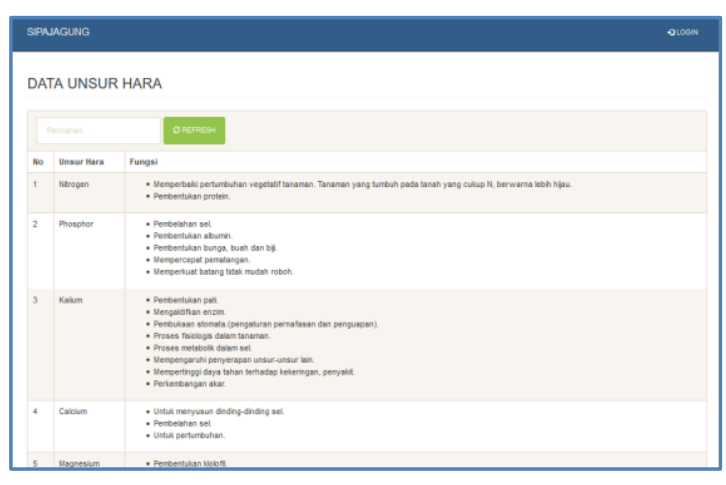

Gambar 4. Halaman Data Unsur Hara
Pada halaman ini terdapat dua kolom unsur hara dan fungsi. Dimana pada halaman ini bertujuan untuk memberikan informasi kepada pengguna tentang pentingnya mengetahui unsur hara apa saja yang ada di dalam tanah dan kegunaan dari setiap unsur hara tersebut bagi tanaman.

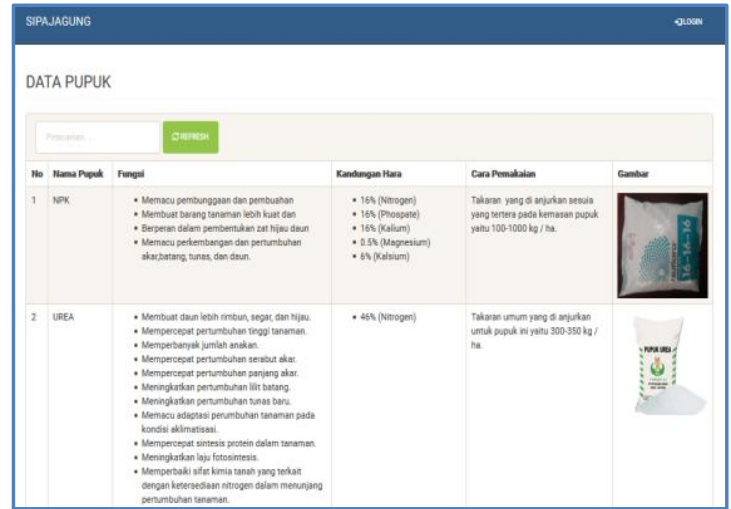

Gambar 5. Halaman Data Pupuk

Pada halaman ini terdapat beberapa kolom seperti pupuk, fungsi, kandungan hara, cara pemakaian, dan terakhir terdapat juga gambar yang berguna memperjelas bentuk dari pupuk yang akan ditampilkan ke halaman pengguna nantinya.

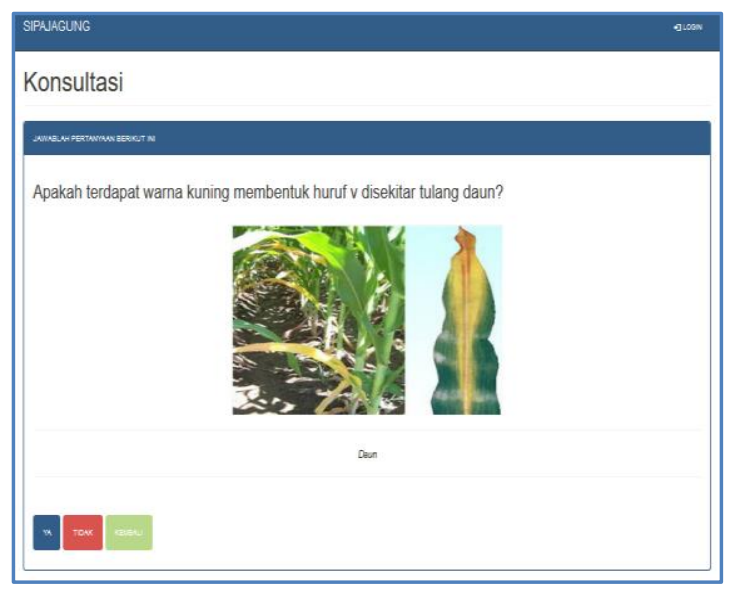

Gambar 6. Halaman Konsultasi

Pada halaman konsultasi terdapat gejalagejala yang akan diajukan oleh sistem ke pada pengguna, yang bertujuan untuk memberikan jawaban dan solusi atas permasalahan yang dialami oleh tanaman jagung tersebut. Disini juga terdapat gambar yang mempermudah pengguna untuk mengenali gejala kekurangan unsur hara 
Jurnal Pseudocode, Volume V Nomor 2, September 2018, ISSN 2355-5920, e-ISSN 2655-1845 www.ejournal.unib.ac.id/index.php/pseudocode

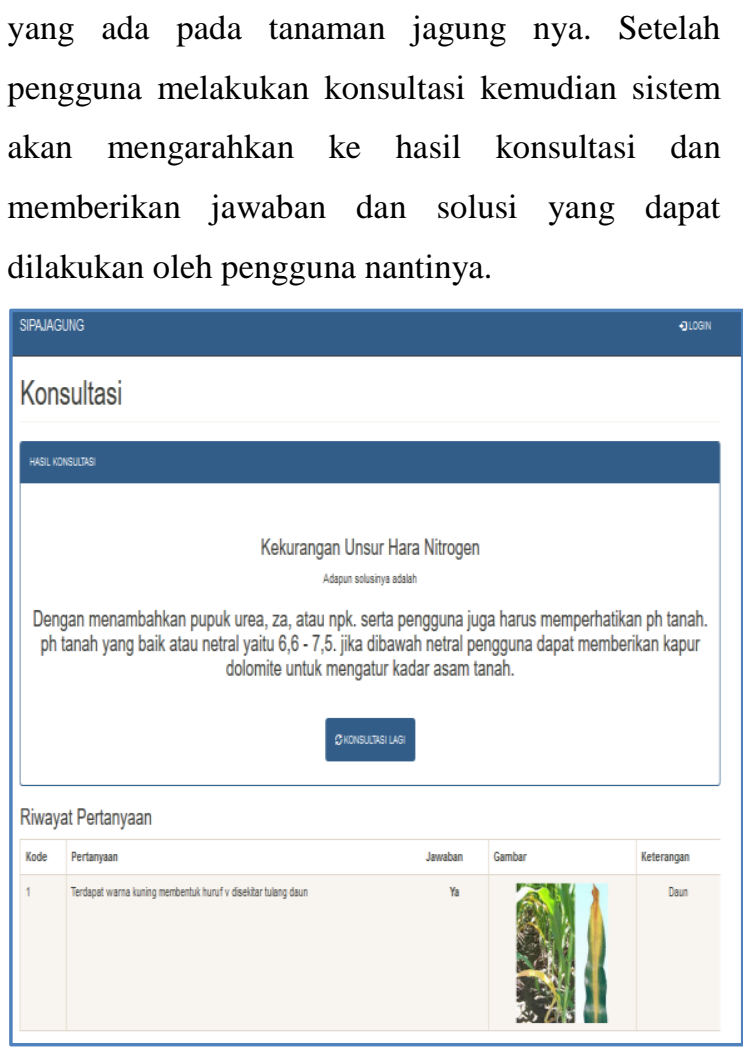

Gambar 7. Halaman Hasil Konsultasi

Setelah pengguna melakukan konsultasi sistem akan mengarahkan ke halaman hasil konsultasi. disini terdapat penjelasan bahwa tanaman ini kekurangan unsur hara apa dan solusinya bagaimana terhadap permasalahan yang di alami oleh tanaman jagung tersebut.

\section{Pengujian Sistem}

Pengujian bertujuan untuk menemukan kesalahan atau kekurangan pada sistem yang akan diuji. Pengujian juga diperlukan untuk mengetahui apakah aplikasi yang telah dibuat memenuhi kriteria yang sesuai dengan tujuan perancangan sistem sebelumnya.

\section{A. Pengujian Black Box}

Pengujian black box adalah suatu pengujian yang dilakukan untuk mengamati hasil eksekusi antarmuka (interface) melalui data uji dan memeriksa fungsional dari sistem yang dibuat.

\begin{tabular}{|l|l|l|l|}
\hline Kelas Uji & $\begin{array}{l}\text { Skenario } \\
\text { Pengujian }\end{array}$ & \multicolumn{1}{|c|}{ Hasil yang } \\
Diharapkan & \multicolumn{1}{|c|}{ Hasil dan } \\
Kesimpulan
\end{tabular}


Jurnal Pseudocode, Volume VI Nomor 2, September 2019, ISSN 2355-5920, e-ISSN 2655-1845 www.ejournal.unib.ac.id/index.php/pseudocode

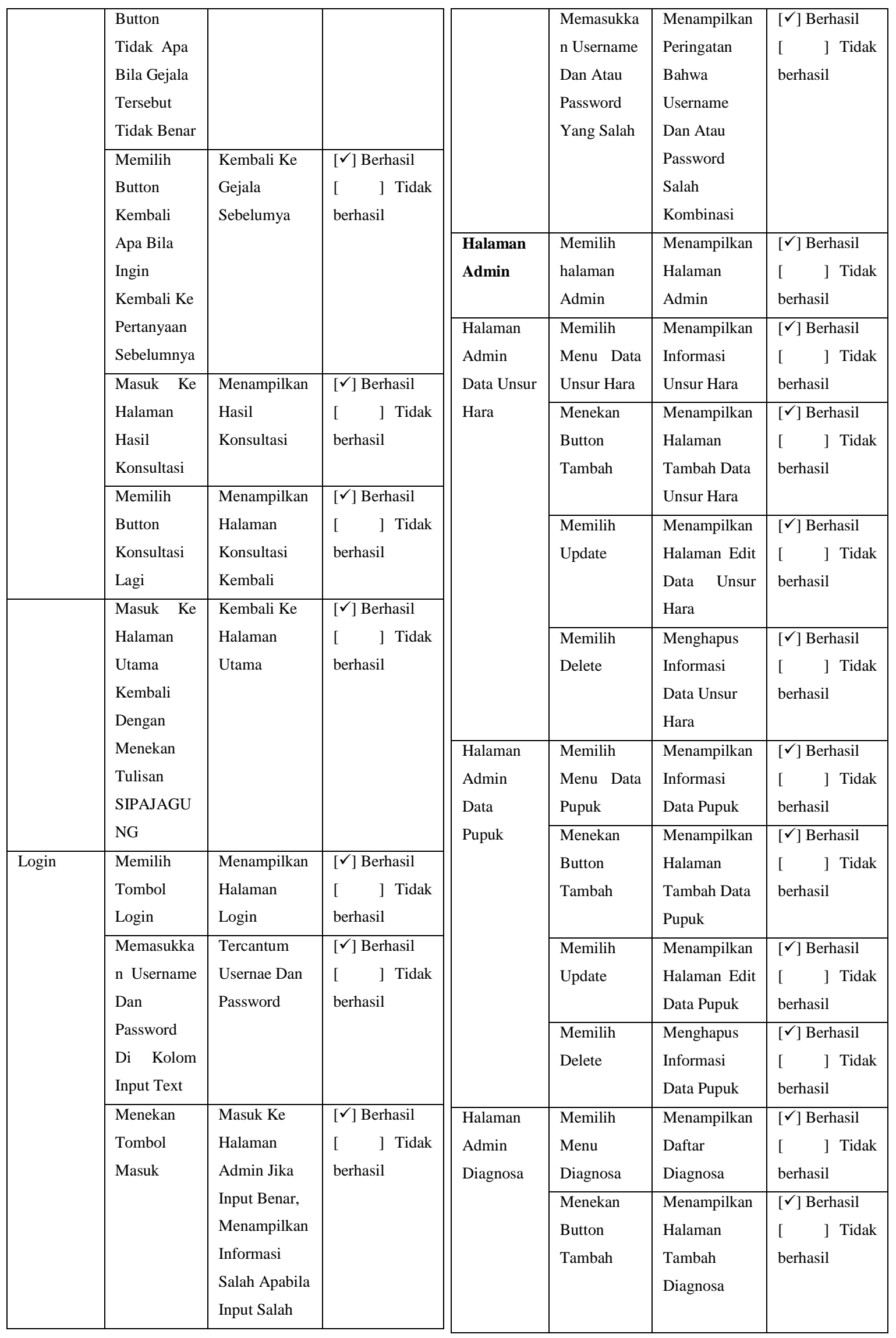


Jurnal Pseudocode, Volume V Nomor 2, September 2018, ISSN 2355-5920, e-ISSN 2655-1845 www.ejournal.unib.ac.id/index.php/pseudocode

\begin{tabular}{|c|c|c|c|}
\hline & $\begin{array}{l}\text { Memilih } \\
\text { Update }\end{array}$ & $\begin{array}{l}\text { Menampilkan } \\
\text { Halaman Edit } \\
\text { Diagnosa }\end{array}$ & 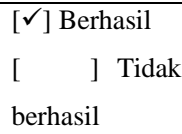 \\
\hline & $\begin{array}{l}\text { Memilih } \\
\text { Delete }\end{array}$ & $\begin{array}{l}\text { Menghapus } \\
\text { Diagnosa }\end{array}$ & $\begin{array}{l}\sqrt{ }\left[\begin{array}{l}\text { Berhasil } \\
{[}\end{array}\right. \\
\text { berhasil }\end{array}$ \\
\hline \multirow[t]{4}{*}{$\begin{array}{l}\text { Halaman } \\
\text { Gejala }\end{array}$} & $\begin{array}{l}\text { Memilih } \\
\text { Menu } \\
\text { Gejala }\end{array}$ & $\begin{array}{l}\text { Menampilkan } \\
\text { Halaman } \\
\text { Gejala Yang } \\
\text { Berisi Daftar } \\
\text { Gejala } \\
\text { Beserta } \\
\text { Gambar }\end{array}$ & $\begin{array}{l}{[\sqrt{ } \text { ] Berhasil }} \\
{\left[\begin{array}{l}{ }^{2} \\
\text { berhasil }\end{array}\right.}\end{array}$ \\
\hline & $\begin{array}{l}\text { Menekan } \\
\text { Button } \\
\text { Tambah }\end{array}$ & $\begin{array}{l}\text { Menampilkan } \\
\text { Halaman } \\
\text { Tambah } \\
\text { Gejala } \\
\text { Beserta } \\
\text { Gambar } \\
\text { Gejala }\end{array}$ & $\begin{array}{l}{[\checkmark] \text { Berhasil }} \\
{\left[\begin{array}{l}\text { berhasil } \\
\text { bidak }\end{array}\right.}\end{array}$ \\
\hline & $\begin{array}{l}\text { Memilih } \\
\text { Update }\end{array}$ & $\begin{array}{l}\text { Menampilkan } \\
\text { Halaman Edit } \\
\text { Gejala }\end{array}$ & $\begin{array}{l}{[\checkmark] \text { Berhasil }} \\
{\left[\begin{array}{l}{ }^{2} \\
\text { berhasil }\end{array}\right.}\end{array}$ \\
\hline & $\begin{array}{l}\text { Memilih } \\
\text { Delete }\end{array}$ & $\begin{array}{l}\text { Menghapus } \\
\text { Gejala }\end{array}$ & 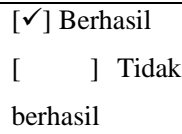 \\
\hline \multirow[t]{4}{*}{$\begin{array}{l}\text { Halaman } \\
\text { Admin } \\
\text { Basis } \\
\text { Pengetahua } \\
\mathrm{n}\end{array}$} & $\begin{array}{l}\text { Memilih } \\
\text { halaman } \\
\text { basis } \\
\text { pengetahua } \\
\text { n }\end{array}$ & $\begin{array}{l}\text { Menampilkan } \\
\text { halaman } \\
\text { basis } \\
\text { pengetahuan }\end{array}$ & $\begin{array}{l}{[\sqrt{ }] \text { Berhasil }} \\
{[\quad] \text { Tidak }} \\
\text { berhasil }\end{array}$ \\
\hline & $\begin{array}{l}\text { Menekan } \\
\text { Button } \\
\text { Tambah }\end{array}$ & $\begin{array}{l}\text { Menampilkan } \\
\text { Halaman } \\
\text { Tambah Yang } \\
\text { Berhubungan } \\
\text { Dengan } \\
\text { Gejala Dan } \\
\text { Diagnosa }\end{array}$ & 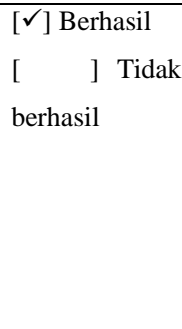 \\
\hline & $\begin{array}{l}\text { Memilih } \\
\text { Update }\end{array}$ & $\begin{array}{l}\text { Menampilkan } \\
\text { Halaman Edit } \\
\text { Basis } \\
\text { Pengetahuan }\end{array}$ & $\begin{array}{l}{[\checkmark] \text { Berhasil }} \\
{\left[\begin{array}{ll} & \text { Tidak } \\
\text { berhasil }\end{array}\right.}\end{array}$ \\
\hline & $\begin{array}{l}\text { Memilih } \\
\text { Delete }\end{array}$ & $\begin{array}{l}\text { Menghapus } \\
\text { Data Basis } \\
\text { Pengetahuan }\end{array}$ & $\begin{array}{l}{[\sqrt{ }] \text { Berhasil }} \\
{\left[\begin{array}{l}{ }^{2} \\
\text { berhasil }\end{array}\right.}\end{array}$ \\
\hline $\begin{array}{l}\text { Halaman } \\
\text { Password }\end{array}$ & $\begin{array}{l}\text { Memilih } \\
\text { Ubah }\end{array}$ & $\begin{array}{l}\text { Menampilkan } \\
\text { Form Ubah }\end{array}$ & $\begin{array}{l}{\left[^{\vee}\right] \text { Berhasil }} \\
{\left[\begin{array}{ll} & \text { Tidak }\end{array}\right.}\end{array}$ \\
\hline
\end{tabular}

\begin{tabular}{|c|c|c|c|}
\hline & $\begin{array}{l}\text { Password } \\
\text { Lama }\end{array}$ & $\begin{array}{l}\text { Password } \\
\text { Lama }\end{array}$ & berhasil \\
\hline & $\begin{array}{l}\text { Memilih } \\
\text { Ubah } \\
\text { Password } \\
\text { Baru }\end{array}$ & $\begin{array}{l}\text { Menampilkan } \\
\text { Form Untuk } \\
\text { Mengubah } \\
\text { Password } \\
\text { Baru }\end{array}$ & $\begin{array}{l}{[\checkmark] \text { Berhasil }} \\
{\left[\begin{array}{l}\text { [ Tidak } \\
\text { berhasil }\end{array}\right.}\end{array}$ \\
\hline & $\begin{array}{l}\text { Memilih } \\
\text { Konfirmasi } \\
\text { Password } \\
\text { Baru }\end{array}$ & $\begin{array}{l}\text { Menampilkan } \\
\text { Password } \\
\text { Baru }\end{array}$ & $\begin{array}{l}{[\checkmark] \text { Berhasil }} \\
{\left[\begin{array}{l}\text { [ Tidak } \\
\text { berhasil }\end{array}\right.}\end{array}$ \\
\hline Logout & $\begin{array}{l}\text { Memilih } \\
\text { logout }\end{array}$ & $\begin{array}{l}\text { Menampilkan } \\
\text { kembali } \\
\text { halaman } \\
\text { pengguna }\end{array}$ & $\begin{array}{l}{[\checkmark \text { ] Berhasil }} \\
\text { [ ] Tidak } \\
\text { berhasil }\end{array}$ \\
\hline \multicolumn{4}{|c|}{$\begin{array}{l}\text { Pengujian white box dilakukan dengan } \\
\text { mengecek semua statement pada program telah } \\
\text { dieksekusi paling tidak satu kali. Pengujian ini } \\
\text { dilakukan pada proses pengembangan sistem yakni } \\
\text { pengujian kode program (coding). Adapun } \\
\text { potongan source code pada website ini adalah } \\
\text { sebagai berikut. }\end{array}$} \\
\hline $\begin{array}{l}29 \\
30 \\
31 \\
32 \\
\end{array}$ & \multicolumn{3}{|c|}{ 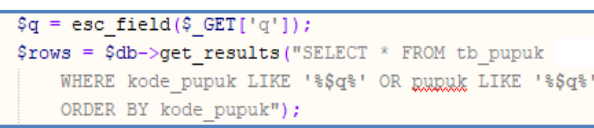 } \\
\hline
\end{tabular}

Sintax ini digunakan untuk mengambil data pupuk yang telah tersimpan di database pada tb_pupuk kemudian data-data tersebut akan ditampilkan ke halaman pengguna.

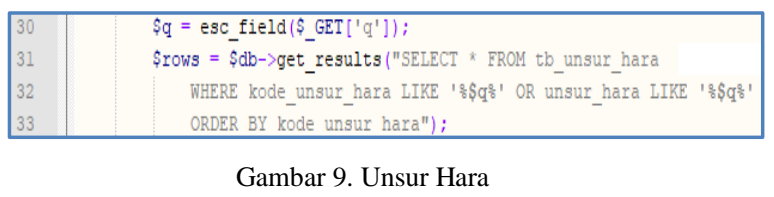

Sintax ini digunakan untuk mengambil data unsur hara yang telah tersimpan di database pada tb_unsur hara kemudian data-data tersebut akan ditampilkan ke halaman pengguna,

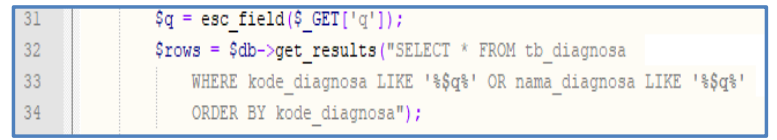

Gambar 10. Diagnosa 
Jurnal Pseudocode, Volume VI Nomor 2, September 2019, ISSN 2355-5920, e-ISSN 2655-1845 www.ejournal.unib.ac.id/index.php/pseudocode

Sintax ini digunakan untuk mengambil data diagnosa yang telah tersimpan di database pada tb_diagnosa kemudian data-data tersebut akan ditampilkan ke halaman pengguna, pada saat pengguna akan melakukan konsultasi data yang telah tersimpan di database sebelumnya akan muncul pada halaman hasil konsultasi .

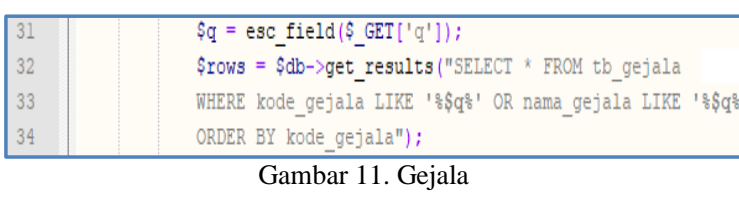

Sintax ini digunakan untuk mengambil data gejala yang telah tersimpan di database pada tb_gejala kemudian data-data tersebut akan ditampilkan ke halaman pengguna. pada saat pengguna akan melakukan konsultasi, data yang telah tersimpan di database sebelumnya akan muncul pada halaman konsultasi. dimana data tersebut ditampilkan dalam bentuk pertanyaan yang merupakan gejala-gejala pada tanaman jagung.

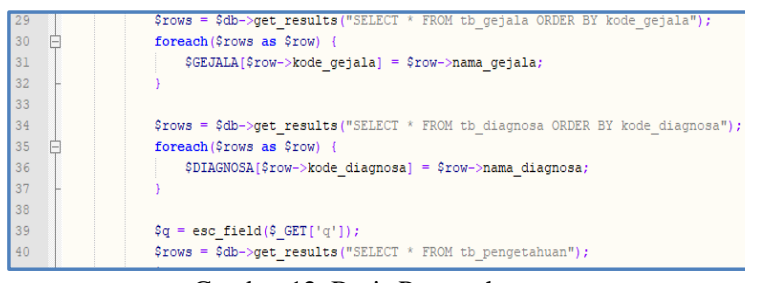

Pada Sintax ini digunakan untuk menentukan aturan atau hubungan antara diagnosa dan gejala yang ada, serta memberikan bobot masing-masing gejala terhadap diagnosa yang telah tersimpan di database pada tb_gejala, tb_diagnosa dan tb_pengetahuan kemudian data-data tersebut akan ditampilkan ke halaman pengguna.

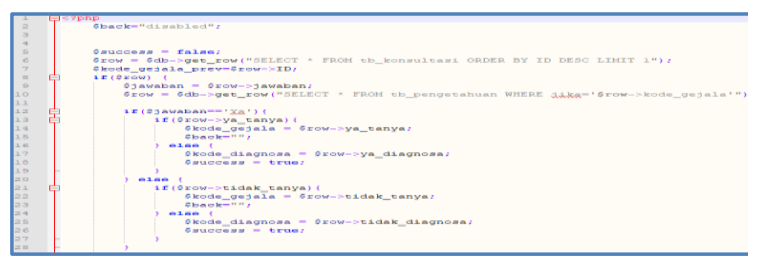

Gambar 13. Konsultasi

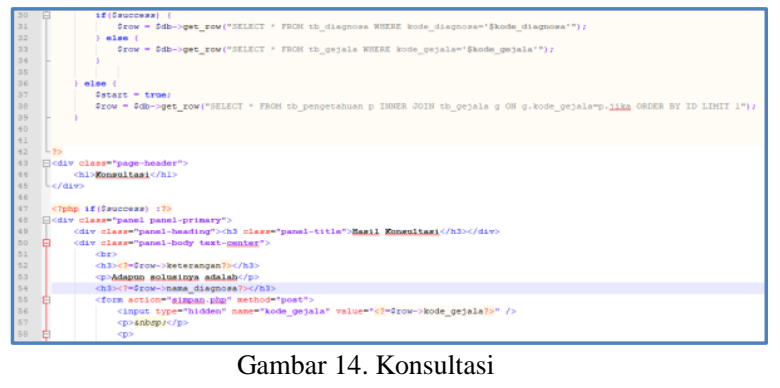

Pada source code ini merupakan code yang berfungsi untuk memanggil data dari tb_konsultasi dengan limit 1 / batasan data yang dipanggila hanya 1. Kemudian jika pemanggilan sukses, maka selanjunya sistem akan memanggil data dari tb_pengetahuan berdasarkan pada gejala dari data di tb_konsultasi.

Jika proses konsultasi telah menemukan diagnosa sesuai dengan gejala-gejala yang dipilih maka sistem akan menampilkan hasil diagnosa beserta gejala-gejala yang telah dipilih.

\section{KESIMPULAN DAN SARAN}

\section{A. Kesimpulan}

Berdasarkan penelitian dan pembahasan hasil yang sudah dilakukan, maka terdapat beberapa kesimpulan yang diperoleh dari penelitian ini, di antaranya sebagai berikut:

1. Penelitian ini telah berhasil membangun aplikasi berbasis web untuk mendiagnosa gejala kekurangan unsur hara pada tanaman jagung pasca penanaman menggunakan metode Forward Chaining (FC) dalam sistem ini memiliki kemampuan:

a. Menampilkan data-data pertanyaan yang terdapat pada menu konsultasi berdasarkan gejala kekurangan unsur hara yang dialami oleh tanaman jagung. Setelah dilakukan konsultasi sistem dapat menampilkan hasil diagnosa berupa data kekurangan unsur hara dan cara penanganannya. 
Jurnal Pseudocode, Volume V Nomor 2, September 2018, ISSN 2355-5920, e-ISSN 2655-1845 www.ejournal.unib.ac.id/index.php/pseudocode

b. Hasil dari konsultasi tersebut berupa rekomendasi pupuk yang dapat digunakan untuk mengatasi kekuranagan unsur hara.

c. Dari hasil pengujian yang telah dilakukan maka dapat disimpulkan bahwa sistem pakar jagung dapat dikategorikan Layak dengan presentase $53,12 \%$.

2. Dari hasil tabulasi kuisioner yang diberikan kepada responden, menunjukkan penilaian "Sangat Baik" dan "Baik" untuk kedua variabel pengujian kelayakan. Presentase persetujuan responden masing-masing yaitu tampilan aplikasi sebesar 90,49 \% dan kemudahan menggunakan aplikasi sebesar 82,67 \% .

\section{B. Saran}

Berdasarkan analisa yang sudah dilakukan terdapat saran yang dapat diberikan dalam pengembangan penelitian kedepannya, saran yang dapat diberikan adalah sebagai berikut :

1. Untuk pengembangan selanjutnya diharapakan sistem dapat menentukan secara langsung takaran atau dosis pupuk yang tepat untuk tanaman jagung.

2. Diharapkan kedepannya bisa mengkombinasikan metode forward chaining dengan metode lainnya seperti: Certainly Factor (CF), Teorema Bayes dan Logika Fuzzy.

\section{REFERENSI}

[1] Arma, Makmur Jaya, dkk. 2013. Pertumbuhan Dan Produksi Jagung (Zea mays L. ) Dan Kacang Tanah (Arachis hypogaea L.) Melalui Pemberian Nutrisi Organik Dan Waktu Tanam Dalam Sistem Tumpangsari.

[2] Siwi. 2016. Perkembangan Produksi Dan Kebijakan Dalam Peningkatan Produksi Jagung.

[3] Hanafiah, Kemas Ali. 2008. Dasar-Dasar Ilmu Tanah. Jakarta : Rajawali Pers

[4] Prasetyo, \& Suriadikarta. 2006. Karakteristik, Potensi Dan Teknologi Pengelolaan Tanah Ultisol Untuk Pengembangan Pertanian Lahan Kering Di Indonesia: Balai Besar Penelitian dan Pengembangan Sumberdaya Lahan Pertanian Bogor.

[5] Rosmarkam, dkk. 2002. Ilmu Kesuburan Tanah. Yogyakarta : Kanisius Yogyakarta.

[6] Kasirah. 2007. Sistem informasi pemupukan lahan pertanian. Mojokerto : Universitas MayJen Sungkono Mojokerto.

[7] Lingga. 2013. Petunjuk Penggunaan Pupuk / Pinus Jakarta: Penebar Swadaya. Jakarta. 